\title{
Santos, Boaventura de Sousa. 2020. A cruel pedagogia do vírus (Pandemia Capital). São Paulo: Boitempo. 35p.
}

\author{
JANAÍNA CAMPOS LOBO \\ UNIVERSIDADE DA INTEGRAÇÃO INTERNACIONAL DA LUSOFONIA AFRO-BRASILEIRA (UNILAB), REDENÇÃO, CE - BRASIL \\ HTTPS://ORCID.ORG/oOoo-000I-9935-4383
}

O ensaio A cruel pedagogia do vírus, escrito pelo sociólogo português Boaventura de Sousa Santos - professor catedrático jubilado da Faculdade de Economia e diretor emérito do Centro de Estudos Sociais (CES), ambos no âmbito da Universidade de Coimbra, em Portugal -, compõe a coleção Pandemia Capital, publicada pela Boitempo Editorial. Os textos, todos em tamanho diminuto, foram disponibilizados apenas em formato digital. O objetivo dessa série de ensaios é difundir um conjunto de reflexões de pensadores, ativistas e intelectuais sobre a crise gerada pelo novo coronavírus.

O ensaio do sociólogo português está dividido em cinco pequenas partes. Na primeira, intitulada Vírus: tudo que é sólido desmancha no ar, Boaventura de Sousa Santos inicia sua análise ao formular uma questão sobre o tempo da pandemia: quais são os conhecimentos que poderíamos tirar de uma degradação mundial na qual houve o alastramento descontrolado do vírus $S a r s-C o V-2$, causador da doença COVID-19 (CoronaVirus Disease - 2019) ? Como provocação e já formulando uma possível resposta, o autor ressalta que a crise da COVID-19 não se enquadra em um tempo de excepcionalidade ou de desequilíbrio, mas é resultado de uma 'normalidade da exceção', a qual se configura por uma situação anômala, gerada a partir de um neoliberalismo sob o jugo do capital financeiro. Tal crise, fruto da versão dominante do capitalismo, causou um colapso permanente, do qual a pandemia é apenas uma das muitas faces perversas. Para o sociólogo, a COVID-19 apenas agrava a situação de descontrole, instabilidade e precariedade que a maioria da população vivencia, de modo muito acentuado, há, pelo menos, quarenta anos.

Parece que o efeito nesse cenário de isolamento social, o qual exigiu transformações urgentes nos modos de vida, sociabilidade e consumo, foi o surgimento de alternativas de existência para além da ideia conservadora, que não considera a existência de outros mundos possíveis fora dos imperativos do capitalismo. Ainda, a pandemia revelou que, mesmo permeada de alvos privilegiados e de atos de discriminação que atingem de modo mais agudo aqueles mais vulneráveis, a segurança oportunizada por condições financeiras mais vigorosas não confere mais a garantia ou a proteção imaginada. A pandemia cria, segundo o autor, alguma consciência de comunhão em escala global. 
No ensaio, vê-se que Boaventura de Sousa Santos está epistemologicamente e politicamente engajado no que nomeou de 'sociologia das ausências', que é a expansão do presente para a compreensão da diversidade das experiências sociais. Nesse sentido, a proposta é produzir uma inteligibilidade sobre as múltiplas invisibilidades que resultam em razão da pandemia. Através dessa reflexão, é possível que consigamos construir um outro futuro civilizatório.

Para que isso seja viável, o sociólogo destaca na segunda parte, nomeada de $A$ trágica transparência do virus, que precisamos derrubar alguns inimigos invisíveis e imprevisíveis como o vírus da COVID-19, por exemplo. Mas, não apenas. O capitalismo, o colonialismo e o patriarcado também se mostram, desde o século XVII, tão insidiosos quanto a atual pandemia. Mesmo que essa tríade, muitas vezes, se apresente enfraquecida (ou, pelo menos, razoavelmente superada), a força destrutiva permanece aparentemente invencível. E, tomadas em conjunto, essas três forças têm o poder de dominar e aniquilar os sujeitos.

Para Sousa, as expressões mais visíveis da força massiva de destruição desses três poderes são a concentração de riqueza (que produz uma miríade de iniquidades sociais) e a aflorante catástrofe ecológica, a qual se anuncia em cada nova destruição das vidas no planeta. Sobre isso, alerta o autor: precisamos pensar essa realidade e colocar nossas categorias e palavras à beira de um abismo. Os intelectuais, em especial, precisam reaprender a se comunicar com o mundo e a refletir sobre a exceção nesses tempos que parecem excepcionais. A tarefa, portanto, diz respeito à capacidade dos pensadores de estarem atentos às urgências dos sujeitos comuns, de modo que haja uma possibilidade de comunicação que oportunize a compreensão das inquietações dessas pessoas, habilidade que, segundo Santos, pastores evangélicos figuram lograr.

A parte três, $A$ sul da quarentena, traz uma ponderação sobre aqueles que estão ao sul no isolamento social. Não se trata de uma posição geográfica, mas de uma fragilidade que indica que a COVID-19 pode afetar, de modo mais drástico, alguns em detrimento de outros. São esses grupos vulneráveis que Boaventura de Souza Santos nomina de 'sul', uma metáfora que evidencia o sofrimento humano e desigual que a pandemia traz consigo. Esse padecimento é motivado pela exploração capitalista e formas discriminatórias, sejam raciais ou sexuais.

Dessa forma, as mulheres estão na berlinda nesta quarentena. Reflexo do machismo e de uma sociedade profundamente arraigada ao poder patriarcal, o isolamento social tende a aumentar os índices de violência doméstica em razão de as vítimas estarem confinadas junto aos seus perpetradores. Além das mulheres, os trabalhadores informais também são mais uma face daqueles que estão ao sul, pois não há garantias específicas de que os rendimentos, já comprometidos com a pandemia, serão mantidos pelos governos que adotam políticas neoliberais.

Por outro lado, o autoisolamento e os trabalhos remotos são possíveis apenas para uma parcela muito reduzida da população. Logo, o autor critica que as recomendações da Organização Mundial da Saúde (OMS) parecem ser dirigidas a uma classe média, de modo que não há correspondência desses alertas com as realidades da maioria dos trabalhadores. Trata-se de uma escolha ilógica: morrer com a COVID-19 ou morrer de fome. Nesse esquema, também se encontram os trabalhadores de tele- entregas e aplicativos de serviços diversos. Não há qualquer viabilidade de seguridade contratual nessas situações. 
A esse coletivo de vulneráveis somam-se as populações em situação de rua, os moradores de áreas periféricas e zonas pobres das cidades. A quarentena, pondera Santos, tende a ser ainda mais cruel quando as condições para atravessá-la são precárias e se configuram como mais um obstáculo à sobrevivência. Como populações que não têm acesso facilitado à água manterão condições mínimas de higiene que reduzam a disseminação da COVID-19? Como atestado de situações críticas, o sociólogo avalia que o isolamento em condições insalubres e débeis tende a ser mais uma experiência dramática para além da pandemia.

As emergências, de que fala Santos, sejam de ordem sanitária, alimentar ou em razão da violência policial, estarão acentuadas neste momento de pandemia. À vista disso, acrescentam-se as emergências dos refugiados, imigrantes, indocumentados, pessoas com deficiência e idosos, os quais também se encontram 'ao sul' nessa circunstância de isolamento. É sob esses aspectos que o autor assevera que a pandemia da COVID-19 potencializou e visibilizou injustiças e exclusões sociais atuantes no mundo.

Mas se o vírus reverbera algum ensinamento, ainda que cruel, a parte quatro do ensaio, $A$ intensa pedagogia do vírus: as primeiras liçôes, objetiva sintetizar quais seriam esses aprendizados. A primeira lição diz respeito às agendas políticas e midiáticas que condicionam como nos apropriamos dos riscos que corremos. A crise climática, que não tem uma resposta tão imediata quanto a crise do corona vírus, está inextrincavelmente interligada, pois é reflexo do tipo de sociedade que começou a se erguer a partir do século XVII, um modelo que terá como resultado catástrofes ecológicas em razão da exploração massiva de recursos naturais e do esgotamento que resulta desse padrão exploratório, o qual infringe o lugar da nossa humanidade.

Ademais, uma lição fundamental da quarta parte do ensaio é entender que a pandemia não atua indiscriminadamente, mas é discriminatória na medida em que alguns atravessarão essa situação com mais recursos que outros. E, nesse âmbito, a terceira lição defendida por Boaventura de Sousa Santos é que o capitalismo não tem futuro, uma vez que não pode mais negligenciar preceitos de cidadania e direitos humanos. O ciclo nefasto do capitalismo precisa ser interrompido para que as populações, em tempos de pandemia, não estejam à mercê das decisões de instituições financeiras internacionais.

Santos também espera que, nessa nova articulação de mundo, que ressurgirá no pós-pandemia, os governos de extrema-direita estejam desacreditados por conta das respostas pífias nas políticas adotadas em combate à COVID-19. A pandemia, consequentemente, expôs que o modelo neoliberal foi incapaz de responder a contento as emergências suscitadas durante o surto do coronavírus.

Por fim, na última seção do ensaio, O futuro pode começar hoje, apesar da crise e do pessimismo que se instalou desde o início da pandemia, essa situação, paradoxalmente - de acordo com Santos -, pode nos indicar alternativas sobre os modos de viver. No entanto, a efetividade dessas mudanças só poderá ocorrer se conseguirmos articular processos políticos e processos civilizatórios, de modo que a nossa humanidade esteja sob revisão através da articulação de muitos aspectos, como os culturais e ideológicos.

O isolamento ocasionado pelo novo coronavírus, para Boaventura de Sousa Santos, nada mais é do que uma quarentena dentro de outra quarentena, já que, por pelo menos quarenta anos, estivemos confinados em um capitalismo fechado sobre si mesmo. É para que nos livremos desses confinamentos 
que uma virada deve ser articulada. E isto somente será possível quando conseguirmos promover, após esse tempo pandêmico, uma reformulação sobre o bem comum: a humanidade, para o autor, precisa assumir uma postura humilde no planeta em que habitamos.

Janaina Campos Lobo é professora adjunta do Instituto de Humanidades da Universidade da Integração Internacional da Lusofonia Afro-brasileira (UNILAB/Ceará) e doutora em Antropologia Social pelo PPGAS/UFRGS.

RECEBIDO: 06/05/2020

APROVADO: $17 / 08 / 2020$ 